\title{
A Fluorescent Probe for Diacetyl Detection
}

\author{
Xiaohua Li • Axel Duerkop • Otto S. Wolfbeis
}

Received: 4 September 2008 / Accepted: 24 November 2008 /Published online: 23 December 2008

(C) Springer Science + Business Media, LLC 2008

\begin{abstract}
A water-soluble fluorescent probe, rhodamine B hydrazide $(\mathrm{RBH})$, was prepared and its properties for recognition of diacetyl were studied. The method employs the reaction of diacetyl with $\mathrm{RBH}$, a colorless and nonfluorescent rhodamine B spiro form derivative to give a pink-colored fluorescent substance. In weakly acidic media, RBH reacts more selectively with diacetyl than with other carbonyls, causing a large increase in fluorescence intensity and thereby providing an easy assay for the determination of diacetyl.
\end{abstract}

Keywords Fluorescent probe $\cdot$ Rhodamine B hydrazide . Diacetyl · Cell medium

\section{Introduction}

Diacetyl (2, 3-butanedione), is produced naturally in many foods, especially in fermented dairy products, and also in many bacteria [1-4]. Therefore, it plays an important role in microbiology and in fermentation technology [1-3]. Literature indicates that the diacetyl contained in food additives may be hazardous when inhaled over a long period, and diacetyl is further suspected to induce various toxic responses, such as lung disease, Alzheimer's disease, mutagenesis, and carcinogenesis $[5,6]$. Hence, diacetyl determination is attractive, also because its concentration is one of the parameters on which lactic acid bacteria are characterized and evaluated [7].

X. Li $\cdot$ A. Duerkop $(\bowtie) \cdot$ O. S. Wolfbeis

Institute of Analytical Chemistry, Chemo- and Biosensors,

University of Regensburg,

93040 Regensburg, Germany

e-mail: axel.duerkop@chemie.uni-r.de
Therefore, it is necessary to develop efficient methods for determination of diacetyl.

So far, a number of assays have been developed for diacetyl. Among them, there are two spectrophotometric methods. One is based on the conversion of diacetyl into dimethylglyoxime and subsequent conversion into a colored metal complex. Alternatively, a colored condensation product with urea is formed. The formation of dimethylglyoxime is slow and requires prolonged heating, which is time consuming and cannot be performed in vivo [8]. The other method, the Westerfeld method [9], was developed to measure diacetyl levels in blood. This original colorimetric assay for diacetyl and acetoin is very simple. Both diacetyl and acetoin react with creatine in the presence of $\alpha$-naphthol to form a chromogenic compound that can be quantified spectrophotometrically. Diacetyl reacts comparatively faster than acetoin, and based on this property, diacetyl was determined successfully in presence of acetoin $[8,10,11]$. Later, when GC was introduced, it became the most frequently used method for diacetyl determination [12-14], and sometimes HPLC is also used [15]. By virtue of high sensitivity and the strong spatial resolution of fluorescence measurements, much interest has been shown in pre-column fluorescent derivatization methods in chromatography [16]. Currently, most of the commonly used derivatization reagents can form quinoline derivatives with $\alpha$-dicarbonyl compounds, such as 2,3-diaminobenzene $[17,18]$. Another way of derivatization is based on the reaction of hydrazide-containing fluorophores with carbonyls. In this way ketones and aldehydes are detected fluorescently $[19,20]$.

However, up to now, the fluorescent reagents developed for diacetyl are mostly excited at very short wavelengths, such as 2,3-diaminobenzene, ABD-H or DBD-H [17-19], 
which may suffer from interference by scatter and tissue absorbance. Therefore, long-wavelength fluorescent probes with excitation wavelengths in the visible region would represent a large progress. Among the longwavelength fluorescent probes, rhodamine derivatives are widely used in biological systems due to their good photostability, water solubility and high quantum yield in aqueous solution [21]. Many unique signaling systems have been developed based on rhodamine B hydrazide, which is a classical example of $\mathrm{Cu}^{2+}$-selective fluorescent chemodosimeter [22, 23].

Our aim is to develop a fluorescent method to detect diacetyl in cancerous cells. The non-fluorescent spiro dye rhodamine $\mathrm{B}$ hydrazide $(\mathrm{RBH})$ was prepared and its selectivity for diacetyl was studied. It was found that $\mathrm{RBH}$ reacts with diacetyl at slightly acidic $\mathrm{pH}$ and undergoes a large increase in fluorescence intensity. $\mathrm{pH}$, buffer and reaction time were optimized and a novel fluorescent method was developed for diacetyl determination. We show its potential for determination of diacetyl in cancerous cells with strong matrix effects by standard addition experiments in cell nutrition medium.

\section{Experimental}

\section{Apparatus}

Absorption spectra were recorded on a Cary 50 Bio UV-Vis spectrophotometer (Varian, Australia, www.varian.com). Luminescence spectra were recorded on an AmincoBowman AB 2 luminescence spectrometer (www.thermo. com) equipped with a $150-\mathrm{W}$ continuous wave xenon lamp as excitation light source. All spectra are uncorrected. Measurements in cells were performed on a BMG Fluostar Optima (www.bmglabtech.com) at $\lambda_{\mathrm{exc}}=560 \mathrm{~nm}$ and $\lambda_{\mathrm{em}}=$ $590 \mathrm{~nm}$ in transparent flat bottom 96-well plates from nunc (www.nunc.de). $\mathrm{pH}$ was measured with a $\mathrm{pH}$ meter CG 842 from Schott (www.schott.com) at room temperature. The ESI mass spectra were taken on a ThermoQuest TSQ 7000 (www.thermo.com) mass spectrometer. The ${ }^{1} \mathrm{H}$ NMR spectra were acquired on an Avance $300 \mathrm{MHz}$ NMR Spectrometer (Bruker-BioSpin GmbH, www.bruker-biospin.com).

\section{Reagents}

Rhodamine B and diacetyl were purchased from Aldrich (www.sigmaaldrich.com). Diacetyl was distilled before use. Stock solutions of RBH $(1.0 \mathrm{mmol} / \mathrm{L})$ and diacetyl were prepared by dissolving an appropriate quantity of the reagents in ethanol.

\section{Synthesis of RBH}

RBH was synthesized according to a method reported in literature [23]. Specifically, $0.5 \mathrm{~g}$ of rhodamine B were dissolved in $20 \mathrm{ml}$ of methanol, an excess of hydrazine hydrate $(0.6 \mathrm{~mL})$ was added, and then the reaction solution was refluxed until the pink color disappeared (Scheme 1). The cooled reaction mixture was then poured into distilled water and extracted with ethyl acetate. The organic layer was dried over anhydrous sodium sulfate, filtered and the solvent was evaporated. The product was recrystallized from methanol-acetone as a colorless solid and the purity is above $99 \%$ by TLC. Yield: $0.36 \mathrm{~g}(70 \%)$ of RBH. MS (ES) $m / z$ : 457.2, $\left([\mathrm{M}+\mathrm{H}]^{+}\right)$; calculated: 456.2 for $\mathrm{M}^{+} .{ }^{1} \mathrm{H} \mathrm{NMR}$ $\left(\mathrm{CDCl}_{3}\right) \delta 7.90(\mathrm{~m}, 1 \mathrm{H}, \mathrm{ArH}), 7.42$ (m, 2H, ArH), 7.10 (m, 1H, ArH), 6.44 (d, 2H, xanthene-H), $6.40(\mathrm{~d}, 2 \mathrm{H}$, xanthene-H), 6.28 (dd, $2 \mathrm{H}$, xanthene-H), $3.58\left(\mathrm{~s}, 2 \mathrm{H}, \mathrm{NH}_{2}\right)$, 3.32 (q, 8H, $\mathrm{NCH}_{2} \mathrm{CH}_{3}$ ), 1.15 (t, 12H, $\mathrm{NCH}_{2} \mathrm{CH}_{3}$ ).

\section{Derivatization procedure for diacetyl}

Twenty microliters of a solution of $\mathrm{RBH}(1 \mathrm{mmol} / \mathrm{L}$ in ethanol) was added to citric acid- $\mathrm{Na}_{2} \mathrm{HPO}_{4}$ buffer of $\mathrm{pH} 3$ (50 $\mathrm{mmol} / \mathrm{L}$ ), followed by addition of diacetyl solution (in ethanol) containing no more than $20 \mu \mathrm{mol} / \mathrm{L}$, and the volume of each diacetyl solution was made up to $1 \mathrm{~mL}$. The same volume of ethanol as the sample solution was added to the control containing RBH only. The tube was then kept at $37 \pm$ $1{ }^{\circ} \mathrm{C}$ for $3 \mathrm{~h}$ before the fluorescence spectra and/or intensities were measured at $563 \mathrm{~nm}$ (exc.) and $586 \mathrm{~nm}$ (em).

Scheme 1 Synthesis of RBH

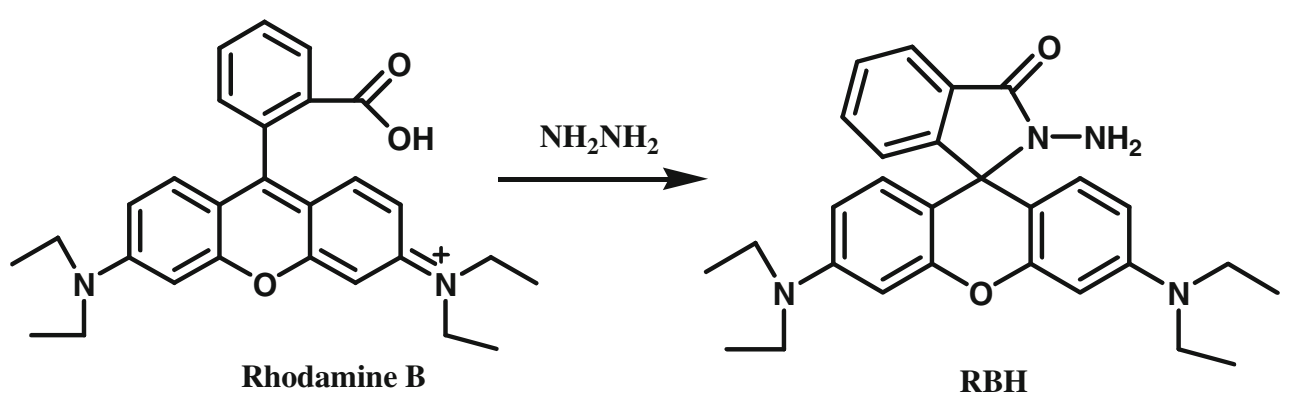




\section{Results and discussion}

\section{Fluorescence spectra of RBH}

The stock solution of RBH in ethanol is colorless, and shows no detectable fluorescence. After addition of a small portion of $\mathrm{RBH}$ stock solution into $\mathrm{pH} 3$ citrate-phosphate buffer and shaking, a faint pink color shows up almost immediately and weak fluorescence can also be detected. In aqueous buffers of $\mathrm{pH} 7$ no such phenomenon appears. The fluorescence spectra of $\mathrm{RBH}$ with or without diacetyl are shown in Fig. 1. RBH and diacetyl in different concentrations were reacted for $3 \mathrm{~h}$ at $37{ }^{\circ} \mathrm{C}$ in $\mathrm{pH} 3$ citratephosphate buffer solutions. As can be seen from Fig. 1, $\mathrm{RBH}$ shows weak fluorescence with $\lambda_{\text {exc/em }}$ at $560 / 590 \mathrm{~nm}$ in $\mathrm{pH} 3$ media. This is due to the formation of a small portion of the ring-opened amide form of $\mathrm{RBH}$ in acidic condition (Scheme 2). After addition of diacetyl to the solution in $\mu \mathrm{mol} / \mathrm{L}$ quantities, the characteristic fluorescence emission of rhodamine B was observed and its pink color recovered to a large extent. Accordingly, the fluorescence intensity increases fourfold. This is accompanied by a $5 \mathrm{~nm}$ red-shift of the emission maximum from $581 \mathrm{~nm}$ to $586 \mathrm{~nm}$ in presence of $200 \mu \mathrm{mol} / \mathrm{L}$. The wavelength of the excitation maximum remains almost unchanged. The fluorescence increase seen upon reaction of $\mathrm{RBH}$ with increasing amounts of diacetyl reaches saturation at a molar ratio of diacetyl to $\mathrm{RBH}$ of $1: 1$. If the concentration of diacetyl is $220 \mu \mathrm{mol} / \mathrm{L}$ or higher, almost no more fluorescence increase appears. We therefore propose that only a 1:1 product is formed, but no product with two molecules of $\mathrm{RBH}$ reacted with one diacetyl. The reasons may be increased steric hindrance for an additional attack at the 1:1 product and a

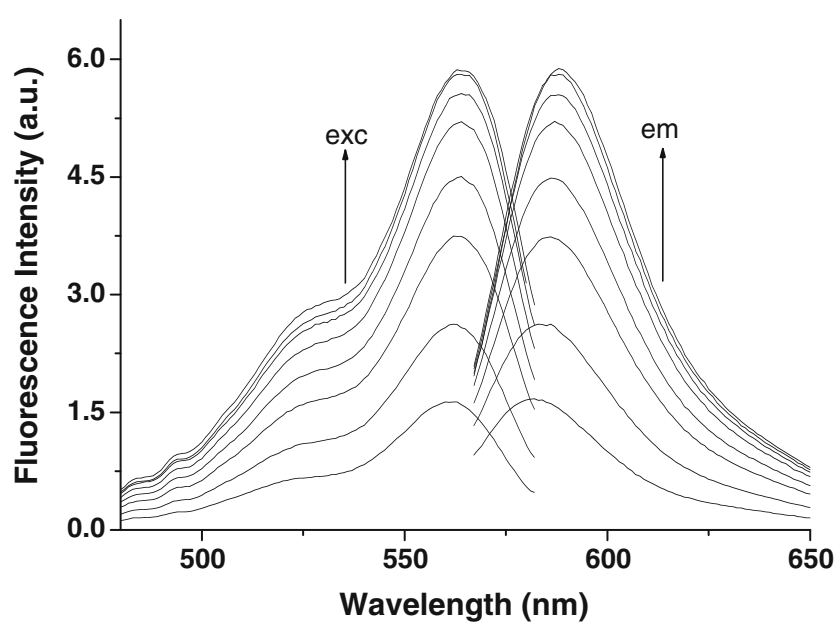

Fig. 1 Fluorescence spectra of RBH before and after reaction with diacetyl. The spectra from bottom to top: $200 \mu \mathrm{mol} / \mathrm{L}$ of RBH with 0 , $40,90,120,150,180,200,220 \mu \mathrm{mol} / \mathrm{L}$ diacetyl in citric acid$\mathrm{Na}_{2} \mathrm{HPO}_{4}$ buffer of $\mathrm{pH} 3$, respectively reduced nucleophilicity of the remaining carbonyl carbon of diacetyl in the $1: 1$ product. Thus, the probe shows a fluorescence-on response to diacetyl and may be used as a probe for diacetyl.

Effect of $\mathrm{pH}$ and reaction time

The effect of $\mathrm{pH}$ on the reaction of $\mathrm{RBH}$ with diacetyl was investigated. Several buffer systems, such as citrate buffer, citrate-phosphate buffer, acetate buffer and phosphate buffer from $\mathrm{pH} 2$ to $\mathrm{pH} 5$, were tested with $200 \mu \mathrm{mol} / \mathrm{L}$ of $\mathrm{RBH}$ and diacetyl at $37^{\circ} \mathrm{C}$ after a $2.5 \mathrm{~h}$ reaction. It was found that the best buffer system for this derivatization reaction is citric acid- $\mathrm{Na}_{2} \mathrm{HPO}_{4}$ of $\mathrm{pH} 3$, in that it gives a more pronounced fluorescence signal than the other systems (Fig. 2).

The reaction rate of $200 \mu \mathrm{mol} / \mathrm{L}$ of $\mathrm{RBH}$ with $100 \mu \mathrm{mol} /$ $\mathrm{L}$ of diacetyl was also examined at $37{ }^{\circ} \mathrm{C}$ and $\mathrm{pH} 3$. Figure 3 shows that after $2.5 \mathrm{~h}$ incubation the derivatization is completed. Due to the pronounced increase of fluorescence intensity, one could also use a kinetic determination after $1.5 \mathrm{~h}$, where more than half of the total fluorescence increase has already appeared.

\section{Absorption spectra of $\mathrm{RBH}$ before and after reaction}

The absorption spectra of RBH $(200 \mu \mathrm{mol} / \mathrm{L})$ before and after the reaction with $100 \mu \mathrm{mol} / \mathrm{L}$ of diacetyl at $37{ }^{\circ} \mathrm{C}$ in pH 3 citrate-phosphate buffer solution $(50 \mathrm{mmol} / \mathrm{L})$ are shown in Fig. 4. In accordance with the change of fluorescence, the absorbance also increases to almost the same degree after reaction with diacetyl. The absorption maximum only slightly changes from $559 \mathrm{~nm}$ to $562 \mathrm{~nm}$. Obviously, the reaction of diacetyl with $\mathrm{RBH}$ causes a structural change in the molecule, as shown in Scheme 2.

Interference by other carbonyls

The reaction of $\mathrm{RBH}$ with various carbonyls was examined under the above conditions to determine the selectivity of the probe for different carbonyls. Ten micromolar per liter of diacetyl and a twice to 13.6-fold molar excess of interferent was reacted with $\mathrm{RBH}$ in $\mathrm{pH} 3$ citrate-phosphate buffer solution $(50 \mathrm{mmol} / \mathrm{L})$ at $37{ }^{\circ} \mathrm{C}$ for $3 \mathrm{~h}$. Then, the enhancement of the emission intensities was compared. Figure 5 indicates that $\mathrm{RBH}$ has a much higher selectivity for diacetyl than for other carbonyls, except that benzylaldehyde shows noticeable interference. However, there is no report which shows that benzylaldehyde is found as a result of metabolism in any physiological process. As we aim to find a reagent to determine diacetyl at physiological concentrations, the interference of benzylaldehyde is not relevant for our purposes. Apart from benzaldehyde, 
Scheme 2 Reaction mechanism of RBH with diacetyl and RBH hydrolysis in acidic buffer

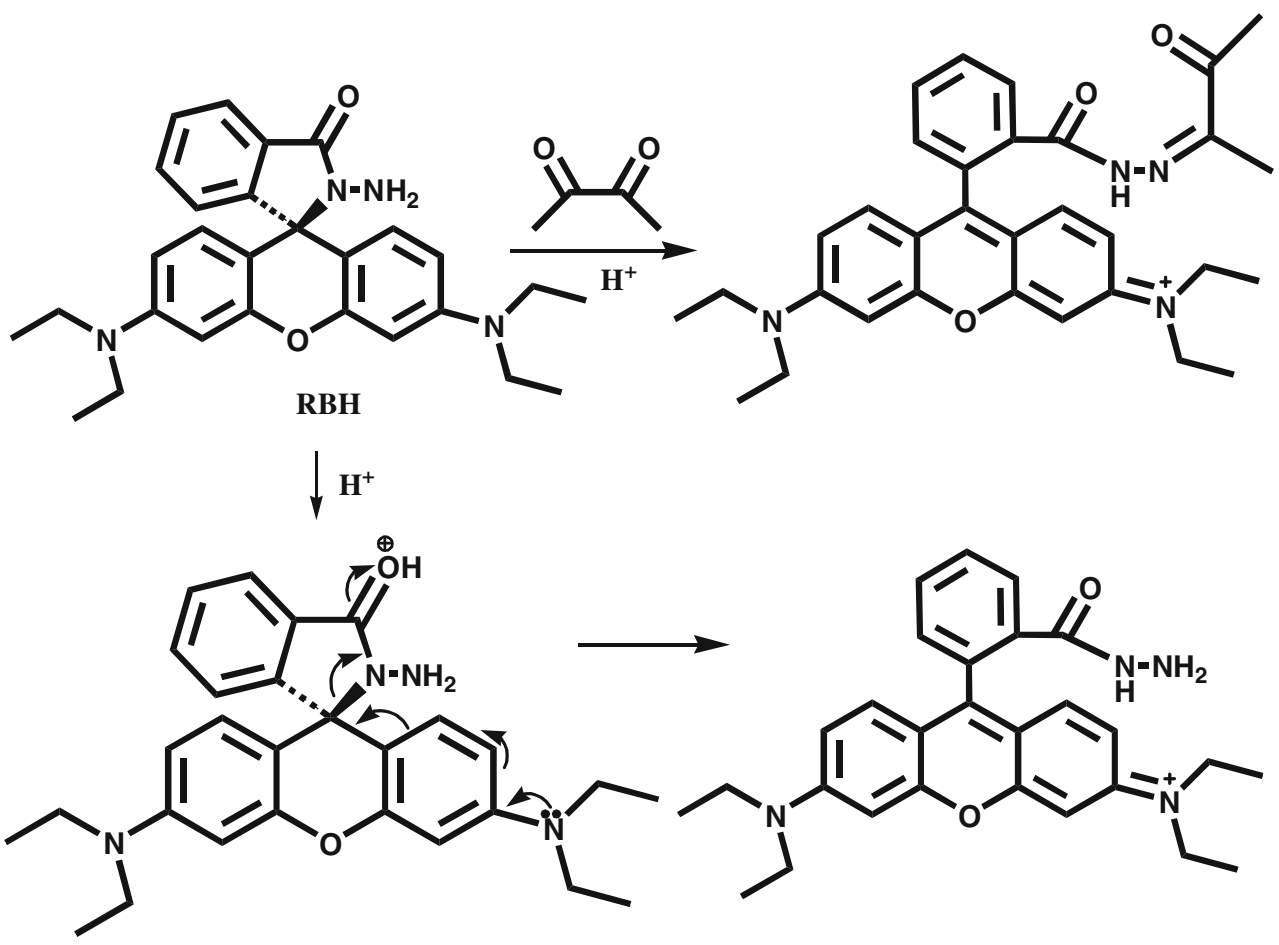

pyruvic acid shows interference if it is present at $20 \mu \mathrm{mol} / \mathrm{L}$. If the emission intensity of pyruvic acid is calculated for the same molar concentration $(10 \mu \mathrm{mol} / \mathrm{L})$ as for diacetyl, however, the signal of pyruvic acid is tenfold lower than that of diacetyl. This $10 \mu \mathrm{mol} / \mathrm{L}$ is the concentration of pyruvic acid one can expect to occur in cell medium [24] or from cell influx and efflux [25]. The selectivity towards other carbonyls on a molar basis varies between 35:1 for glyoxal and 200:1 for acetaldehyde. Although glyoxal and pyruvic acid are more electrophilic compounds than diacetyl and thus should show faster reaction kinetics with

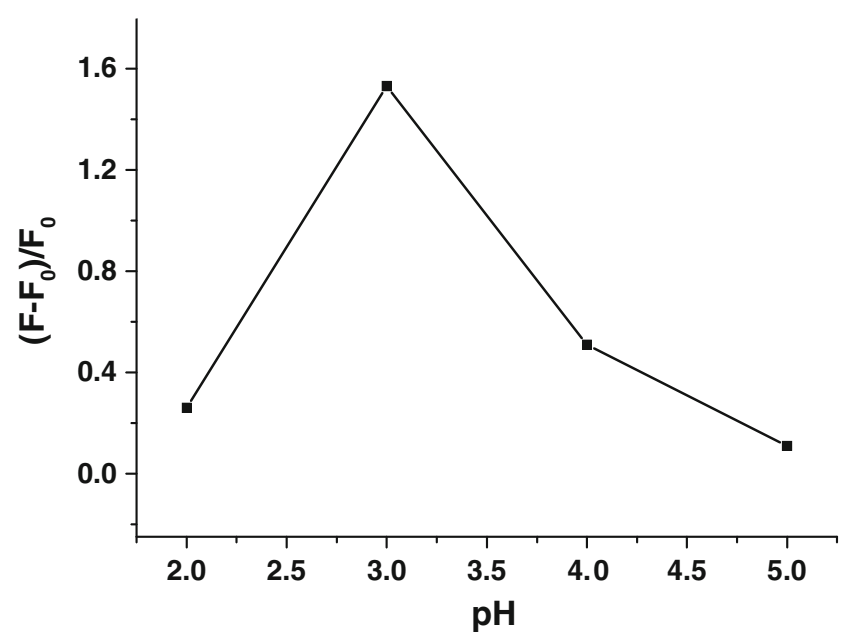

Fig. 2 Effect of $\mathrm{pH}$ on the reaction of $\mathrm{RBH}$ with diacetyl. $\mathrm{HCl}$, $0.01 \mathrm{~mol} / \mathrm{L}$, was used as $\mathrm{pH} 2$ buffer. Concentration of both $\mathrm{RBH}$ and diacetyl is $200 \mu \mathrm{mol} / \mathrm{L}$
$\mathrm{RBH}$, lower emission intensities of the respective reaction products after a reaction time of $3 \mathrm{~h}$ are found, reproducibly. We currently do not have an explanation for this phenomenon. Therefore, interferences are unlikely to be a problem for this probe to be applied for diacetyl detection in the cases where diacetyl is the dominant carbonyl species to be determined.

\section{Preliminary test in cell medium}

The derivatization method was tested in the supernatant of some cell lines. Three different cell lines (SW620, LS174 and SW837) were allowed to undergo their usual metabolism activity in RPMI 1640 Biochrom medium for 2 days. During this period, the medium is enriched with metabolism products and low-molecular weight carbonyl compounds released from the cells. This increases the matrix effect of the supernatant, additionally. RPMI as such is a strong matrix itself because it contains buffer salts and salts for adjustment of ionic strength in $\mathrm{g} / \mathrm{L}$ concentrations, all 20 amino acids in up to hundreds of $\mathrm{mg}$ / $\mathrm{L}$, the vitamins $\mathrm{B}_{1}, \mathrm{~B}_{2}, \mathrm{~B}_{6}, \mathrm{~B}_{12}$; biotin, folic acid and other compounds in lower quantities [26, 27]. After 2 days, the cells were removed by centrifugation and the medium was adjusted to $\mathrm{pH} 3$ with $\mathrm{HCl}$. Unspiked cell medium was tested on its effect on $\mathrm{RBH}$ by mixing of $100 \mu \mathrm{L}$ of cell supernatant, $40 \mu \mathrm{L}$ of $\mathrm{RBH}$ and $60 \mu \mathrm{L}$ of citric acid$\mathrm{Na}_{2} \mathrm{HPO}_{4}$ buffer of $\mathrm{pH} 3$. From the solid lines in Fig. 6 (curves I, III and V), it is obvious that luminescence increased by a factor between 2 and 5 . This points out, that certain amounts of carbonyls were present in the 


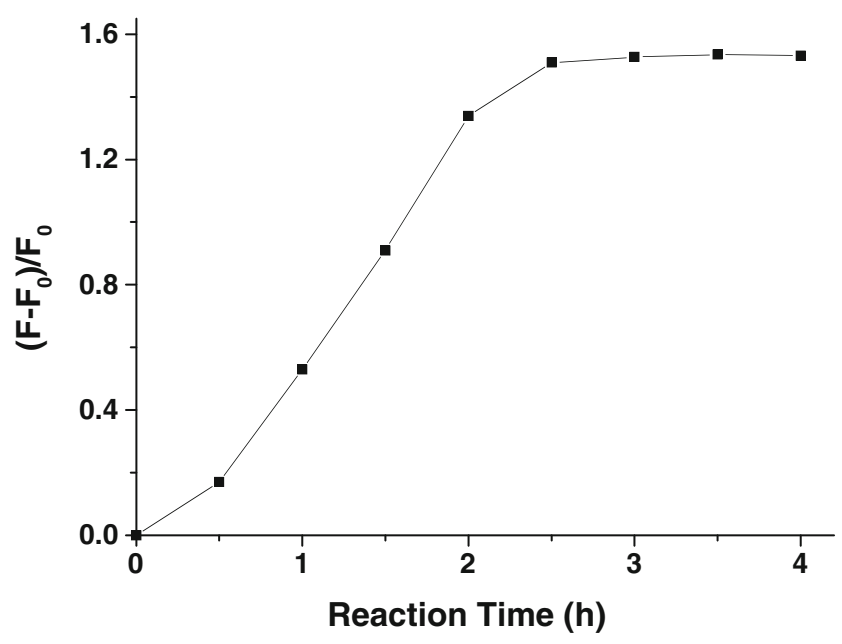

Fig. 3 Effect of reaction time on the reaction of RBH with diacetyl. Conditions: $200 \mu \mathrm{mol} / \mathrm{L}$ of RBH, $100 \mu \mathrm{mol} / \mathrm{L}$ of diacetyl, reacted at $37{ }^{\circ} \mathrm{C}$ in $\mathrm{pH} 3$ citrate-phosphate buffer solution $(50 \mathrm{mmol} / \mathrm{L})$

supernatants. The increase in luminescence is completed after about $1 \mathrm{~h}$. This is a shorter time compared to the detection of pure diacetyl and hints to the existence of more reactive carbonyl than diacetyl. We then spiked the cell supernatant with diacetyl $(60 \mu \mathrm{L}$ of supernatant, $40 \mu \mathrm{L}$ of $\mathrm{RBH}, 40 \mu \mathrm{L}$ of $200 \mu \mathrm{mol} / \mathrm{L}$ of diacetyl and $60 \mu \mathrm{L}$ of buffer) to judge on the capability of RBH to detect diacetyl in the presence of a potentially strongly interfering matrix. On comparing the luminescence of the supernatants spiked with diacetyl with the unspiked samples (I and II, III and IV, V and VI), it is visible that for each cell line, there is a

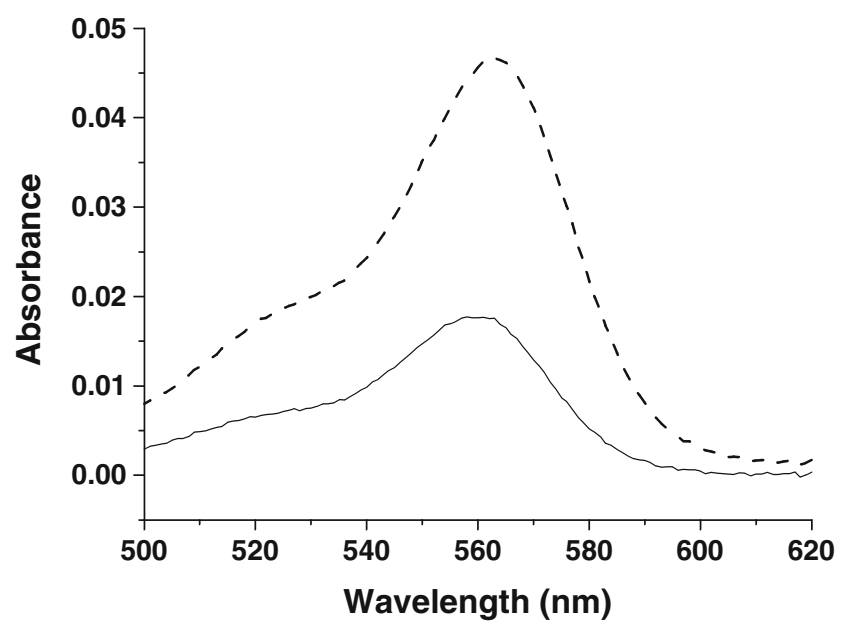

Fig. 4 Absorption spectra of RBH before (solid line) and after (dashed line) reaction with diacetyl. Conditions: $200 \mu \mathrm{mol} / \mathrm{L}$ of $\mathrm{RBH}$, $100 \mu \mathrm{mol} / \mathrm{L}$ of diacetyl; reacted in $\mathrm{pH} 3$ citrate-phosphate buffer $(50 \mathrm{mmol} / \mathrm{L})$ at $37{ }^{\circ} \mathrm{C}$ for $3 \mathrm{~h}$

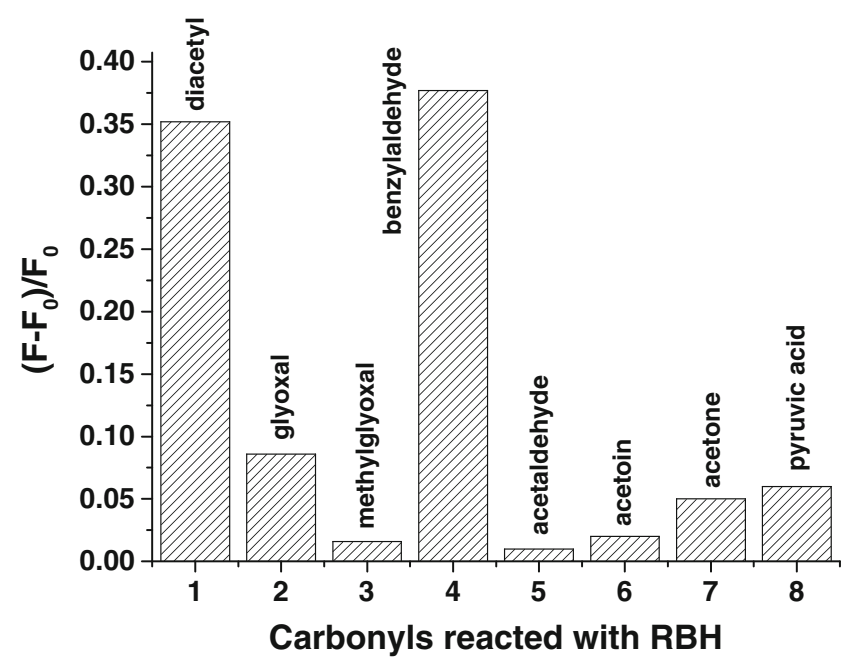

Fig. 5 Fluorescence increase of RBH caused by diacetyl or other carbonyls as potential interferents after reaction in $\mathrm{pH} 3$ citratephosphate buffer $(50 \mathrm{mmol} / \mathrm{L})$ at $37{ }^{\circ} \mathrm{C}$ for $3 \mathrm{~h}$. The concentration of diacetyl is $10 \mu \mathrm{mol} / \mathrm{L}$. For other carbonyls the concentration is 87.5 , $65,60,100,50,136$ and $20 \mu \mathrm{mol} / \mathrm{L}$ for glyoxal, methylglyoxal, benzylaldehyde, acetaldehyde, acetoin, acetone and pyruvic acid, respectively

luminescence increase compared to the unspiked supernatant. As the reaction of the spiked samples still takes $3 \mathrm{~h}$ to be completed, we deduce that the additional fluorescence increase compared to unspiked samples is due to the presence of diacetyl. This shows that RBH can be used as a fluorescent probe for diacetyl in cell medium as well as in other matrixcontaining media in the $\mu \mathrm{mol} / \mathrm{L}$-concentration range, and thus might become a suitable reagent for a rapid screening test for cancerous cells.

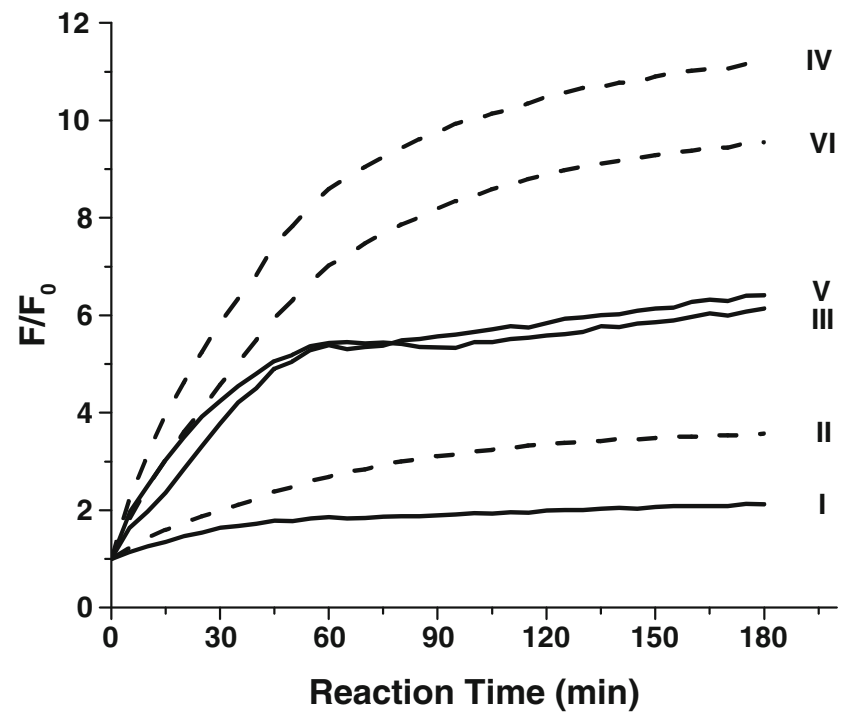

Fig. 6 Luminescence of supernatants of cancer cell lines before and after spiking with diacetyl. Solid lines $(I, I I I$ and $V$ ) represent unspiked and dashed lines (II, $I V$ and $V I)$ represent spiked samples of SW620 ( $I$ and $I I$ ), LS174 (III and $I V$ ) and SW837( $V$ and $V I)$, respectively. A $560 \mathrm{~nm}($ exc.) $/ 590 \mathrm{~nm}(\mathrm{em})$ filter combination was used 


\section{Conclusion}

The fluorescent probe RBH is introduced for determination of diacetyl. To our knowledge, this is the first time that RBH was used as a probe for diacetyl. It shows good selectivity to diacetyl compared to other carbonyls of physiological relevance. A preliminary test for detection of cell-released diacetyl in cell medium in $\mu \mathrm{mol} / \mathrm{L}$ concentrations was successful. Further investigation of this probe for detection of diacetyl in cancer cell culture is now in progress. We think that the present derivatization reaction may offer a convenient way for detection of diacetyl in vitro, and thus to detect cancerous cells at an early stage.

Acknowledgement We thank Dr. Herbert Stepp and Tobias Beck from the LFL (Laser-Forschungslabor, University of Munich) for the measurement of cell samples. Financial support from the BMBF (German Ministry for Education and Research) within the Biophotonik II programme for the joint project "Tumor Vision" is gratefully acknowledged.

\section{References}

1. Lozano PR, Miracle ER, Krause AJ, Drake M, Cadwallader KR (2007) Effect of cold storage and packaging material on the major aroma components of sweet cream butter. J Agric Food Chem 55:7840-7846 doi:10.1021/jf071075q

2. Cabral ME, Mukdsi MCA, Medina de Figueroa RB, Gonzalez SN (2007) Citrate metabolism by enterococcus faecium and enterococcus durans isolated from goat's and ewe's milk: influence of glucose and lactose. Can J Microbiol 53:607-615 doi:10.1139/W07-011

3. Ferreira ACdaS, Reis S, Rodrigues C, Oliveira C, Guedes de Pinho P (2007) Simultaneous determination of ketoacids and dicarbonyl compounds, key Maillard intermediates on the generation of aged wine aroma. J Food Sci 72:S314-S318 doi:10.1111/ j.1750-3841.2007.00368.x

4. Chuang LF, Collins EB (1968) Biosynthesis of diacetyl in bacteria and yeast. J Bacteriol 95:2083-2089

5. Kovacic P, Cooksy AL (2005) Role of diacetyl metabolite in alcohol toxicity and addiction via electron transfer and oxidative stress. Arch Toxicol 79:123-128 doi:10.1007/s00204-004-0602-Z

6. Stoner GD, Shimkin MB, Kniazeff AJ, Weisburger JH, Weisburger EK, Gori GB (1973) Test for carcinogenicity of food additives and chemotherapeutic agents by the pulmonary tumor response in strain a mice. Cancer Res 33:3069-3085

7. Macciola V, Candela G, Leonardis A (2008) Rapid gas-chromatographic method for the determination of diacetyl in milk, fermented milk and butter. Food Contr 19:873-878 doi:10.1016/ j.foodcont.2007.08.014

8. Campo G, Carmen ML (1992) Spectrophotometric determination of biacetyl in distillates of wine by flow injection. Analyst (Lond.) 117:1343-1436 doi:10.1039/an9921701343

9. Westerfeld WW (1945) A colorimetric determination of blood acetoin. J Biol Chem 161:495-502

10. Goldschmidt MC, Lockhart BM (1971) Simplified rapid procedure for determination of agmatine and other guanidino-containing compounds. Anal Chem 43:1475-1479 doi:10.1021/ac60305a026

11. Mattessich J, Cooper JR (1989) The spectrophotometric determination of diacetyl. Anal Biochem 180:349-350 doi:10.1016/00032697(89)90443-0
12. Parish ME, Braddock RJ, Wicker L (1990) Gas chromatograph detection of diacetyl in orange juice. J Food Qual 13:249-258 doi:10.1111/j.1745-4557.1990.tb00021.x

13. Otsuka M, Ohmori S (1992) Simple and sensitive determination of diacetyl and acetoin in biological samples and alcoholic drinks by gas chromatography with electron-capture detection. J Chromatogr B Analyt Technol Biomed Life Sci 577:215-220

14. Ferrari G, Lablanquie O, Cantagrel R, Ledauphin J, Payot T, Fournier N, Guichard E (2004) Determination of key odorant compounds in freshly distilled cognac using GC-O, GC-MS, and sensory evaluation. J Agric Food Chem 52:5670-5676 doi:10.1021/jf049512d

15. Montville TJ, Meyer ME, Hsu HMA, Huang GTC (1987) High pressure liquid chromatography and widebore capillary gas-liquid chromatography methods for quantification of acetoin and diacetyl from bacterial cultures. J Microbiol Methods 7:18 doi:10.1016/0167-7012(87)90002-9

16. Craig DB, Wetzl BK, Duerkop A, Wolfbeis OS (2005) Determination of picomolar concentrations of proteins using novel reactive chameleon labels and capillary electrophoresis laserinduced fluorescence detection. Electrophoresis 26:2208-2213 doi:10.1002/elps.200410332

17. Espinosa-Mansilla A, Duran-Meras I, Salinas F (1998) Highperformance liquid chromatographic-fluorometric determination of glyoxal, methylglyoxal, and diacetyl in urine by prederivatization to pteridinic rings. Anal Biochem 255:263-273 doi:10.1006/ abio.1997.2470

18. De Revel G, Pripis-Nicolau L, Barbe JC, Bertrand A (2000) The detection of a-dicarbonyl compounds in wine by formation of quinoxaline derivatives. J Sci Food Agric 80:102-108 doi:10.1002/(SICI)1097-0010(20000101)80:1<102::AIDJSFA493>3.0.CO;2-Y

19. Uzu S, Kanda S, Imai K (1990) Fluorogenic reagents: 4-Aminosulphonyl-7-hydrazino-2,1,3-benzoxadiazole, 4-(N,N-DimethylaminosuIphonyl)-7-hydrazino-2,1,3-benzoxa-diazole and 4-hydrazino-7-nitro-2,1,3-benzoxadiazole hydrazine for aldehydes and ketones. Analyst (Lond.) 115:1477-1482 doi:10.1039/ an9901501477

20. Houdier S, Legrand M, Boturyn D, Croze S, Defrancq E, Lhomme J (1999) A new fluorescent probe for sensitive detection of carbonyl compounds. Anal Chim Acta 382:253-263 doi:10.1016/S0003-2670(98)00722-3

21. Shi W, Ma H (2008) Rhodamine B thiolactone: a simple chemosensor for $\mathrm{Hg}^{2+}$ in aqueous media. Chem Commun 16:1856-1858 doi:10.1039/b717718f

22. Dujols V, Ford F, Czarnik AW (1997) A long-wavelength fluorescent chemodosimeter selective for $\mathrm{Cu}(\mathrm{II})$ ion in water. $\mathrm{J}$ Am Chem Soc 119:7386-7387 doi:10.1021/ja971221g

23. Yang XF, Liu P, Guo XQ, Zhao YB (2002) Development of a novel rhodamine-type fluorescent probe to determine peroxynitrite. Talanta 57:883-890

24. Wu YS, Tsai TH, Wu TF, Cheng FC (2001) Determination of pyruvate and lactate in primary liver cell culture medium during hypoxia by online microdialysis-liquid chromatography. J Chromatogr A 913:341347 doi:10.1016/S0021-9673(00)01265-6

25. Portais JC, Schuster R, Merle M, Canioni Pz (1993) Metabolic flux determination in $\mathrm{C} 6$ glioma cells using carbon-13 distribution upon $\left[1-{ }^{13} \mathrm{C}\right]$ glucose incubation. Eur J Biochem 217:457-468 doi:10.1111/j.1432-1033.1993.tb18265.x

26. Moore GE, Gerner RE, Franklin HA (1967) Culture of normal human leukocytes. JAMA 199:519-524 doi:10.1001/ jama.199.8.519

27. Ham RG, McKeehan WL (1979) Media and growth requirements. Methods Enzymol 58:44-93 doi:10.1016/S0076-6879 (79)58126-9 